\title{
Flexible Word Definition of School-Aged Children with Specific Language Impairment
}

\author{
Moon Ja Shin ${ }^{a}$, Hee Ran Lee ${ }^{\mathrm{b}}$ \\ ${ }^{a}$ Department of Speech Language Pathology, Chosun University, Gwangju, Korea \\ ${ }^{b}$ Department of Speech and Hearing Therapy, Catholic University of Pusan, Busan, Korea
}

Correspondence: Hee Ran Lee, PhD Department of Speech and Hearing Therapy, Catholic University of Pusan, 57 Oryundae-ro, Geumjeong-gu, Busan 46252, Korea

Tel: +82-51-510-0841

Fax: +82-51-510-0848

E-mail: hrlee@cup.ac.kr

Received: January 5, 2016

Revised: February 3, 2016

Accepted: February 15, 2016

\begin{abstract}
Objectives: The purpose of the present study was to investigate flexible word definition in Korean school-aged children with specific language impairment (SLI). Flexible words are those with one phonological form but two or more distinctive meanings. Methods: Fifteen children with SLI (SLI group) and fifteen vocabulary ability-matched typically developing children (TD group) participated in this study. The children were asked to define both meanings (a dominant and a subordinate meaning) of the presented 15 polysemous words. The definitions were categorized into four types: functional, relational, physical, and classificational definitions. Results: The SLI group exhibited lower performances than the TD group on the definition task, but the two groups were not significantly different. The subordinate meaning definitions tested lower than the dominant meaning in both groups. SLI children used significantly fewer types of definitions than the TD group in both the dominant and subordinate meanings, but the two groups'scores were not significantly different. Conclusion: The results indicated that SLI children have similar verbal definition production skills with language age-matched typically developing children. They tend to rely more on dominant definitions whereas lexical ambiguity expressive strategies were available to the typical developing children. Flexible word definition is considered useful for assessing the vocabulary knowledge of school-aged children with specific language impairment.
\end{abstract}

Keywords: Specific language impairment, Flexible word, Verbal definition, Language acquisition, School-aged children
영유아 시기 언어발달에 어려움을 보인 아동들 중에는 학령기에 이르러 교실담화에 참여하거나 읽기, 쓰기 등 학습에 필요한 언어 수행에 어려움을 보이는 아동들이 있다. 특히 어휘발달의 경우 학 령전기에는 일상생활의 경험과 관련하여 어휘를 습득하는 것이 주 가 된다면 학령기에는 교과서를 중심으로 한 학습용 어휘나 학교 생활과 학생 개인의 경험을 넘어선 탈문맥적인(decontextualized) 의미를 이해하고 표현하기 위한 어휘발달이 요구된다.

이러한 학령기 어휘발달에 어려움을 보이는 아동들 중 청력손 실, 구강구조와 기능 혹은 지능에 문제가 없이 언어능력에만 제한 을 보이는 단순언어장애(specific language impairment)아동은 새 로운 어휘를 학습하는 데에도 어려움을 나타낸다. 일반아동이 일 반적으로 12 개월경에 첫 낱말을 산출하는 반면 이들은 초기 낱말 습득이 지체되어 있으며 이후 어휘발달에서도 또래 아동들에 비해
습득한 어휘의 양이나 어휘를 사용하는 능력이 뒤떨어진다(Leonard, 2014). 단순언어장애아동의 어휘습득능력과 관련하여 연구자 들은 이들이 새로운 낱말을 빠르게 습득하는(fast mapping) 능력, 이름대기, 낱말 찾기 능력 등이 일반아동에 비해 뒤떨어져있다고 보고하고 있다(Lee, 2005; Rice, Buhr, \& Nemeth, 1990; Rice, Buhr, \& Oetting, 1992). 이러한 특성은 단순언어장애아동들의 학업수행 에도 영향을 줄 수 있는데 기존에 이뤼지던 어휘능력 평가 과제만 으로는 이들이 나타내는 어휘습득능력의 근본이 되는 문제들이 드러나기 어렵다. 기존의 언어평가 도구들이 주로 '네/아니요(yes/ no)' 반응만으로 평가를 하고 있는 반면, 이러한 반응만으로는 '안 다(known)'는 것만 파악할 수 있으므로 많은 단계가 있는 어휘습 득 과정에 대한 평가에는 한계가 있을 것이다.

최근 연구자들은 단순언어장애아동이 보이는 의미론적 결함에 
대한 근본적인 기제를 설명하기 위해 낱말정의하기 과제, 의미점화 과제, 낱말을 그림으로 표현하는 과제 등을 이용하여 다양한 측면 으로 연구를 진행하고 있다(Jang, Jeong, \& Hwang, 2014; Lee \& Kim 2003; Lee \& Lee, 2006; Lee \& Ha, 2015; Marinellie \& Johnson, 2002; McGregor \& Appel, 2002). 학령 전 단순언어장애아동을 대 상으로 낱말에 대한 ‘의미 설명하기 과제’와 ‘그림으로 표현하기 과 제'를 수행하게 했을 때 이들은 일반아동보다 두 과제 모두에서 수 행력이 떨어져 언어뿐 아니라 시각적 의미표상에도 결함을 보였으 며(Lee \& Ha, 2015), 의미관련성을 판단하는 의미점화과제에서도 정확도와 반응속도에서 일반아동보다 정확도가 떨어졌고 반응속 도도 느렸다(Lee \& Kim, 2003). 또한 단순언어장애아동들의 어휘 습득은 어휘집(lexicon)에 저장된 '어휘력'이 또래 아동에 비해 적 은 특성을 지니므로(Gray, 2006), 이러한 어휘력 결함이 다양한 의 미론적 이해 및 표현 결함으로 이어질 수 있다.

일반적으로 낱말정의하기는 장기기억 속에 저장되어 있는 의미 표상의 정도를 평가하기 위해 주로 사용되는 방법이다(McGregor \& Appel, 2002). 특히, 단순언어장애아동은 낱말을 정의하는 내용 (content)과 형태(form)에서 일반아동에 비해 현저하게 낮은 수행 능력을 보였다. 낱말을 정의하는 형태에서 단순언어장애아동은 일 반아동보다 상위 범주어(superordinate)를 포함하는 형식적인(for$\mathrm{mal}$ ) 정의 사용에 어려움을 보였으며(Gutierrez-Cleflen \& DeCurtis, 1999), 개념을 언어로 설명하는 경우 단어에 대한 정보가 부족 하였고 구문사용 능력에 있어서도 구나 절, 간단한 문장을 사용하 는 등 미숙한 구문능력을 나타냈다(Marinellie \& Johnson, 2002). 구체 명사에 대한 정의내리기 연구 이외에도 Lee와 Lee (2006)는 어 휘적 모호성을 가진 단어(ambiguous word)를 이용하여 학령 전 단 순언어장애아동이 개별어휘와 문장수준에서 어휘적 모호성 단어 를 처리하는 방식을 살펴보았다. 연구결과, 단순언어장애아동은 개 별어휘 정의하기에서 우세의미를 정의할 때는 일반아동과 비슷한 결과를 보여주었으나, 열세의미 정의하기에는 결함을 보였으며 문 장맥락에서도 열세의미를 처리하는 데 어려움을 보였다. 하지만, 단순언어장애아동이 문장 맥락의 우세의미 정의하기에서 일반아 동과 유사한 능력을 보여주었다는 것은 언어처리과정에서 의미적 처리와 통사적 처리가 독립적으로 이뤄질 수 있음을 시사한다고 연 구자들은 해석하고 있다. 즉, 어휘적 모호성 단어 정의하기의 결함 은 처리과정상의 결함이라기보다는 낮은 수준의 단어 저장능력 또 는 수행상의 결함으로 해석되는 것이 바람직하다는 것이다. 한 낱 말에 대한 정의하기와 비교하면 동음이의어의 정의하기는 좀 더 복 잡하거나 정교한 의미 설명이 요구된다. 특히, 어휘적 모호성을 나 타내는 낱말들은 중의성(ambiguity) 측면에서 동음이의어(hom- onyms)와 다의어(polysemy)로 나누어질 수 있다. 동음이의어는 하 나의 음운 형태가 두 개 이상의 서로 다른 의미를 갖는 것으로(Storkel \& Maekawa, 2005), 예를 들어, ‘바람'은 '자연에서 부는 바람'과 '사람이 바라는 소망'의 두 가지 뜻이 있지만 서로 연관성은 없다. 반면, 다의어는 둘 이상의 의미가 서로 연관성을 지닌 것으로 '머리' 처럼 '사람이나 동물의 목 위의 부분, '생각하고 판단하는 능력', '머 리털'의 의미로 기본의미와파생의미가 서로 관련되어 있기도 하다. 한편, 한 가지 단어 내 두 가지 의미의 친숙도가 같지 않을 수 있는 데, 예를 들어 우리말의 '은행'은 '금융기관'과 '식물'을 각각 의미한 다. 이때 금융기관과 관련된 의미가 좀 더 많이 사용되므로 이를 '우 세하다(dominant)'라고 하고, '식물'의 의미를 '열세하다(subordinate)'로 본다(Whitney, 1999). 대부분의 경우에 우세한 의미가 먼 저 선택되고 난 후 열세한 의미가 선택되지만 여기에는 단어의 사 용, 노출, 경험 등의 요인이 영향을 미치게 된다.

하나의 단어가 여러 가지 의미로 해석된다는 것을 아동이 이해 하기 위해서는 충분한 어휘 양과 어휘지식이 뒷받침되어야 하는데, 동음이의어에 대한 이해능력은 비교적 낮은 연령인 4-5세경부터 발달하기 시작해 학령기 초반부터 본격적으로 형성되어 가지만 10 세가 되기까지는 여전히 어려움을 보인다고 알려져 왔다(Cairns, Waltzman, \& Schlisselberg, 2004; Doherty, 2004; Mazzocco, 1997; Storkel \& Maekawa, 2005). 또한 동음이의어를 이해하는 능력은 연 령에 따라 다를 뿐 아니라 읽기기술과도 관련이 있어 읽기능력에 따라 동음이의어를 이해하는 능력에 차이를 보였다고 한다(Booth, Harasaki, \& Burman, 2006). 읽기이해부진아동은 동음이의어에 대한 의미판단의 정확도가 일반아동에 비해 저조하였으며(Kang, Hwang, \& Lim, 2013), 동음이의어 낱말을 중재했을 때 어휘지식뿐 아니라 읽기이해능력도 향상되는 것을 발견할 수 있었다(Nelson \& Stage, 2007). 이는 동음이의어의 여러 가지 의미에 대한 이해능력 이 낱말 수준에 그치는 것이 아니라 문장 속에서 어떤 의미로 사용 되었는지 알고, 문장 전체의 의미를 바르게 해석하는 데 영향을 주 기 때문이다. 그러므로 동음이의어를 이해하는 능력은 학령기에 습득해야 할 과제임과 동시에 어휘지식(vocabulary knowledge)과 상위언어능력(metalinguistic ability)을 평가할 수 있는 민감한 평 가과제라고 할 수 있다(Corthals, 2010).

새로운 낱말을 학습하고 습득한 낱말을 저장하여 인출하는 데 어려움이 있는 단순언어장애아동은 저장하고 있는 어휘의 양뿐만 아니라 어휘지식의 부족으로 학업성취에 어려움을 겪을 가능성이 있다. 그러나 어휘의 양을 측정하는 기존의 표준화된 평가도구만 으로는 이러한 의미론적 결함을 면밀하게 살피기에 부족함이 있으 므로 학업성취와 읽기, 쓰기 발달에 밀접하게 관련된 정의하기 능 
력을 중심으로 학령기 단순언어장애아동의 어휘지식 특성을 살펴 볼 필요가 있다.

따라서 본 연구에서는 정의하기 과제를 통해 학령기 단순언어장 애아동의 동음이의어 정의하기 능력을 살피고자 한다. 동음이의어 정의하기 과제는 단순언어장애아동의 의미론적 결함 문제를 살펴 볼 수 있는 적절한 도구일 수 있으며, 이들이 학교생활에서 학업을 수행하고 교실담화에 참여를 도울 수 있는 과제로 이용할 수 있기 때문이다. 이런 맥락에서 학령기 단순언어장애아동의 동음이의어 이해 과제 수행능력에 대한 연구는 이들의 상위언어능력과 어휘지 식의 결함을 설명하는 데 의미가 있을 것이다. 본 연구에서는 학령 기 단순언어장애아동과 어휘력 수준을 일치시킨 일반아동을 대상 으로 동음이의어 정의하기에 차이가 있는지를 보고, 이러한 차이 가 이들의 언어처리 또는 수행능력을 반영하는지와 더불어 그 표현 특성을 살펴보고자하였다.

\section{연구 방법}

\section{연구대상}

본 연구에 참가한 아동들은 부산 지역에 거주하는 학령기 단순 언어장애아동 15 명이었으며, 단순언어장애아동과 어휘력검사 결 과를 일치시킨 일반아동 15 명을 포함하여 총 30 명이었다. 단순언어 장애아동 집단은 Leonard (2014)의 단순언어장애 진단기준을 참조 하였으며, 언어재활사 1 급 자격증을 소지하고 임상경력 5 년 이상인 연구자가 이들을 선정하였다. 첫째, 부모 및 교사에 의해 지적 능력 은 정상범주이나 언어 능력과 관련해서는 부족함을 보이는 것으로 보고되었으며, 둘째, 비언어성지능검사(Korean Comprehensive Test of Nonverbal Intelligence-Second Edition, K-CTONI-2; Park, 2014)에서 비언어성 지능이 85 이상이면서, 셋째, 수용-표현어휘력 검사(Receptive and Expressive Vocabulary Test, REVT; Kim, Hong, Kim, Jang, \& Lee, 2009) 결과, 수용어휘력과 표현어휘력 모두 - 1.25 $\mathrm{SD}$ 미만이며, 마지막으로, 시각과 청각 등 신경학적 관련 감각장애 와 정서 및 행동 문제를 보이지 않은 아동으로 선정하였다.

일반아동 집단은 부모와 교사의 보고에 의해 시각 및 청각 등 감 각 장애와 정서 및 행동 문제를 보이지 않는다고 보고된 아동들 중, 첫째, 수용·표현어휘력검사(REVT; Kim et al., 2009) 결과에서, 수 용어휘력과 표현어휘력 모두 단순언어장애 집단과 등가연령이 \pm 3 개월 이내에 속하며, 둘째, 비언어성지능검사(K-CTONI-2; Park, 2014)에서 비언어성 지능이 85 이상인 아동들로 선정하였다.

단순언어장애아동 집단의 생활연령은 평균 10 세 3 개월이었으며 (8세 1개월-12세 5개월), 일반아동 집단은 평균 9세 7개월(8세 0 개
Table 1. Participants' characteristics

\begin{tabular}{lcc}
\hline Characteristic & SLl group (N=15) & TD group (N=15) \\
\hline Age (mo) & $123.60(17.91)$ & $114.93(11.67)$ \\
Nonverbal IQ & $100.26(11.41)$ & $101.73(18.11)$ \\
Receptive vocabulary $^{\mathrm{b}}$ & $101.60(15.52)$ & $104.86(12.39)$ \\
Expressive vocabulary $^{b}$ & $100.80(15.50)$ & $101.80(13.23)$ \\
\hline
\end{tabular}

Values are presented as mean (SD).

$\mathrm{SLI}=$ children with specific language impairment; $\mathrm{TD}=$ vocabulary ability consensus typically developing children.

aKorean Comprehensive Test of Nonverbal Intelligence-2 (Park, 2014), 'beceptive and Expressive Vocabulary Test (Kim, Hong, Kim, Jang, \& Lee, 2009).

월-11세 3개월)이었다. 단순언어장애아동 집단의 수용어휘력과 표 현어휘력은 각각 8 세 4 개월이었으며, 일반아동 집단은 수용어휘력 이 8 세 7 개월, 표현어휘력은 8 세 4 개월이었다. 연구대상 아동에 대 한 자세한 정보는 Table 1 과 같다.

두 집단에 대한 연령의 통제가 잘 이뤄졌는지를 확인하기 위하여 집단 간 $t$-test를 실시한 결과, 수용어휘력 점수 $(t=-.637, p=.187)$ 와 표현어휘력 점수 $(t=-.190, p=.709)$ 모두에서 단순언어장애아동 집 단과 일반아동 집단 간에 유의한차이가 없었으며, 비언어성 지능에 서도 두 집단 간에 유의한 차이가 없는 것으로 나타났다 $(t=-.265$, $p=.357)$. 두 집단의 생활연령 간에는 유의미한 차이가 있었다 $(t=$ $1.57, p<.01)$. 단순언어장애아동 집단은 남아가 6 명, 여아가 9 명이었 으며, 일반아동 집단은 남아가 5 명, 여아가 10 명이었다.

\section{검사 단어 선정}

본 연구에서는 Shin과 Lee (2015)에서 사용된 동음이의어 검사 단어를 사용하였다. Shin과 Lee (2015)의 연구는 학령기 아동의 낱 말표현 능력을 평가하기 위하여 현재 국내에서 일반 초등학생을 대 상으로 표준화가 진행 중인 우리말 낱말표현검사(Urimal Word Semantic Expressive Test, UW-SET)의 실제 적용에서의 타당도와 신뢰도를 살펴본 연구이다. 우리말 낱말표현검사에는 정의하기, 연 관성 찾기, 의미적오류 찾기, 동음이의어 설명의 네 가지 하위검사 가 포함되어 있으며, 학령기 아동들의 표현어휘력을 측정하는 도구 로서 공인타당도, 구인타당도 및 신뢰도가 입증되었다. 본 연구에 서는 이 가운데 동음이의어 검사의 15 개 검사 단어를 사용하였다.

연구에서 선정된 15 개의 단어에는 '눈' '밤' 등의 보통명사와 더 불어, '바람'과 같은 추상명사가 포함되었으며, '타다', '적다'와 같은 서술어가 포함되었다(Appendix 1).

\section{연구 절차}

검사는 언어병리학을 전공하는 학부생과 대학원생이 검사의 내 
용과 실시 절차에 관한 훈련과 실제 적용 연습을 거친 후 진행하였 다. 동음이의어 검사를 위해서는 대략 10 분 정도의 시간이 소요되 었다.

검사 대상 학생이 속한 초등학교나 학원의 교실 또는 공부방과 같은 조용하고 독립된 장소에서 검사를 실시하였으며, 검사자와아 동이 일대일로 마주 앉아 개별적으로 진행하였다. 검사를 실시하기 전에 간단한 인사하기로 아동과의 라포를 형성한 후, 검사자는 아 동에게 동음다의어 단어에 대하여 단어의 뜻을 말하도록 질문하 였다. 각 아동마다 2 개씩의 연습문항을 실시하였으며, 충분히 절차 를 이해하도록 한 후 본 검사를 실시하였다. 먼저, 아동과 마주 앉 아, "선생님이 지금부터 낱말을 들려줄 거에요. 그런데 이 낱말은 뜻 이 여러 개 있어요. 그 뜻을 모두 말해주세요."라고 아동에게 지시 한 후, 연습문항을 실시하였다. 연습문항을 실시할 때, 아동이 단어 의 한 가지에 해당하는 뜻만 이야기하면 다른 한 가지 뜻을 말할 수 있도록 촉진하였다. 연습 문항 이외에 본 검사문항에서는 어떠한 단서도 제공하지 않았다. 아동이 정의하기에 대한 충분한 반응을 보이지 않을 경우, “다시 말해주겠니?" “그것 말고 또 다른 뜻이 있 는데 ..” 등의 간단하지만 통제된 반응하기를 해주어, 아동이 동음 이의어의 여러 가지 의미에 대한 뜻을 충분히 말할 수 있는 기회를 제공하였다.

검사 결과는 검사를 실시하는 즉시 그 자리에서 기록하였으며, 가능한 녹음을 동시에 진행한 후, 검사자가 직접 기록지와 녹음 결 과를 비교하는 작업을 거쳐, 검사 결과 처리에 신뢰도를 높일 수 있 게 하였다.

\section{분석 기준과 자료 처리}

\section{정의정확도 분석}

선행 연구(Bowers, Huisingh, LoGiudice, \& Orman, 2004)를 참 고하여, 동음이의어의 두 가지 의미 모두에 대한 정확한 정의가 이 뤼졌는지를 평가하기 위해 전체 정의정확도를 분석하였다. 전체 정 의정확도 분석에서는 두 가지 단어의 정의를 모두 정확하게 말하면 2점, 두 가지 중 한 가지 정의만 맞고 다른 한 가지의 정의가 미흡하 면 1점, 한 가지 의미만 부분적으로 말하거나 그 외 관련 없는 의미 를 말하면 0 점으로 처리하였다. 또한, 우세의미와 열세의미 각각에 대한 정의정확도 분석을 위해서는 Park과 Kim (2000)의 연구를 참 고하여 개별적으로 분석하였다. 명사 단어의 경우에는 단어의 주요 특성과 상위어, 추가적인 특성을 모두 정확하게 말하는 경우 2점 (예: ‘병'-유리병. 뭔가를 담는 길다란 용기), 한 가지 특성만을 맞게 말하는 경우 1점을 부여하였으며, 관련이 없는 특성이나 무반응에 대해서는 0 점으로 처리하였다. 동사와 형용사를 포함한 서술어의
경우에는 완전하고 정확하게 사전적인 의미를 포함하여 단어의 핵 심이 표현되면 2점(예: ‘타다'택시 같은 교통수단을 이용해 이동하 기 위해 타는 것), 의미적으로 연결된 서술어를 사용하여 정의하면 1 점, 전혀 다른 의미나 무반응에 대해서는 0 점으로 채점하였다. 또 한 차, 달다, 바람 등 정의반응이 두 개 이상이 될 수 있는 단어들이 있었으나, 아동들의 반응이 두 가지 이상 이어지지 않았으므로 분 석에서 고려하지 않았다.

\section{정의유형 분석}

정의유형은 선행연구(Marinellie \& Chan, 2006; Park \& Kim, 2000)를 참고하여 기능적, 관계적, 물리적, 분류적의 네 가지로 분 류하였다. 아동의 단어 정의하기 반응에 따라 각 정의유형별 빈도 를 분석하였으며, 아동이 한 단어에 대하여 여러 개의 문장으로 답 하였을 경우에는 각각을 유형별 분석에 포함시켰다. 각 정의유형의 종류와그 특징에 따른 예는 Appendix 2에 제시하였다.

\section{통계 처리}

수집된 자료는 SPSS ver. 20.0 for Window를 이용하여 분석하였 다. 단순언어장애아동 집단과 언어연령을 일치시킨 일반아동 집단 간의 전체 정의정확도에 차이가 있는 지를 알아보기 위해 일원분 산분석을 실시하였으며, 집단 간 우세의미와 열세의미 개별 정의정 확도 산출에 유의한 차이가 있는지 알아보기 위해서는 2 요인 반복 측정 분산분석을 실시하였다.

\section{신뢰도}

검사 실시 후 일주일 이내에 기록된 결과의 정의정확도 분석을 완료하였다. 정의정확도 분석은 연구자와 두 명의 대학원생이 실시 하였으며, 분석 자료 중 $10 \%$ 에 해당하는 자료를 무작위로 선택하 여 이에 대한 재분석을 실시하였다. 재분석 일치도는 $98 \%$ 였다.

또한, 정의유형 분석 결과에 대한 신뢰도를 검증하기 위하여 분 석자 간 신뢰도를 산출하였다. 분석자 간 신뢰도는 일치된 평가치를 일치된 평가치와 불일치된 평가치를 합한 수치로 나눈 다음 100 을 곱하여 계산하였다. 전체 분석 대상 자료의 $10 \%$ 에 대하여 분석자 간 분석을 평가한 결과, 정의유형 분석 일치도는 $96 \%$ 로 나타났다.

\section{연구 결과}

\section{집단 간 정의정확도 비교}

15 개의 동음이의어 정의하기에 대한 정의정확도를 전체 정의정 확도와 우세의미와 열세의미 각각의 개별 정의정확도로 나누어 분 
Table 2. Performance by word meaning condition in two groups (unit: score)

\begin{tabular}{lcc}
\hline & SLI group & TD group \\
\hline Dominant meaning & $14.20(2.04)$ & $14.66(3.06)$ \\
Subordinate meaning & $10.86(2.64)$ & $11.26(3.03)$
\end{tabular}

Values are presented as mean (SD)

$\mathrm{SLI}=$ children with specific language impairment; $T D=$ vocabulary ability consensus typically developing children.

석하였다. 우선, 전체 정의정확도를 분석한 결과, 단순언어장애아 동 집단은 평균 16.46 (6.59)점, 어휘력검사 결과를 일치시킨 일반아 동 집단은 평균 19.13 (6.42)점으로 일반아동 집단에서 전체 정의정 확도 점수가 높게 나타났다. 두 집단 간에 통계적으로 유의미한 차 이가 있는지를 알아보기 위해 일원분산분석을 실시한 결과, 전체 정의정확도 점수에서는 집단 간 차이가 유의미하지 않았다 $\left(F_{(1,28)}=\right.$ $1.25, p=.272)$. 즉, 동음이의어 단어 정의하기 과제에서 단순언어장 애 집단은 일반아동 집단보다 전체 정의정확도 점수가 낮았지만, 이러한 집단 간 차이가 통계적으로는 유의미하지 않았다.

우세의미와 열세의미 각각에 대한 개별 정의정확도 점수를 분석 한 결과, Table 2에서와 같이 단순언어장애 집단이 일반 집단보다 우세의미와 열세의미 모두에서 수행이 저조하였으며, 특히 이러한 차이는 열세의미 정의정확도에서 보다 두드러졌다. 이러한 차이가 통계적으로 유의미한지 알아보기 위해 2요인 반복측정 분산분석 을 실시한 결과, 집단 간 차이는 나타나지 않았으며 $\left(F_{(1,28)}=.250\right.$, $p=.621)$, 집단 내 요인으로 열세의미와 우세의미에 따른 주효과는 유의미하였다 $\left(F_{(1,28)}=46.917, p<.001\right)$. 즉, 두 집단 모두 우세의미에 대한 정의정확도 점수가 더 높았다. 하지만, 열세의미와 우세의미에 따른 집단간 상호작용효과는 나타나지 않았다 $\left(F_{(1,28)}=.005, p=.946\right)$.

\section{집단 간 단어 정의유형 비교}

두 집단의 우세의미와 열세의미 정의하기 결과에 대해 기능적, 물리적, 관계적, 분류적 네 가지의 정의유형을 분석한 결과는 Table 3과 같다.

두 집단 모두 열세의미보다 우세의미에서 비교적 정의유형 산출 수행이 높았으며, 물리적 반응 유형 산출이 가장 많았다. 우세의미 정의유형에 대한 반응은 두 집단이 유사하였지만, 단순언어장애 아동은 열세의미 정의하기에서도 지각적 특징이 포함된 물리적 유 형에 대한 반응이 가장 많았던 반면, 일반아동 집단은 기능적과 관 계적 정의유형의 빈도가 높았다. 우세의미와 열세의미의 정의유형 을 합하여 집단 간 네 가지 정의유형 산출을 비교한 결과에서도, 정의유형 산출은 두 집단 모두 물리>기능>관계>분류 순으로 나 타났다.
Table 3. Definition types by word meaning condition in two groups (unit: frequency)

\begin{tabular}{lcclll}
\hline & \multicolumn{2}{c}{ SLI group } & & \multicolumn{2}{c}{ TD group } \\
\cline { 2 - 3 } \cline { 6 - 7 } & $\begin{array}{c}\text { Dominant } \\
\text { meaning }\end{array}$ & $\begin{array}{c}\text { Subordinate } \\
\text { meaning }\end{array}$ & & $\begin{array}{c}\text { Dominant } \\
\text { meaning }\end{array}$ & $\begin{array}{c}\text { Subordinate } \\
\text { meaning }\end{array}$ \\
\hline Functional response & $3.80(1.20)$ & $2.47(1.72)$ & & $3.80(2.14)$ & $3.67(2.32)$ \\
Relational response & $2.13(1.50)$ & $1.80(1.52)$ & & $2.40(1.88)$ & $2.53(2.10)$ \\
Physical response & $5.93(1.79)$ & $3.67(1.83)$ & & $5.93(2.76)$ & $2.93(2.15)$ \\
Classificational response & $1.27(1.28)$ & $1.27(1.16)$ & & $1.20(1.20)$ & $1.00(1.00)$ \\
\hline
\end{tabular}

Values are presented as mean (SD).

$\mathrm{SLI}=$ children with specific language impairment; $\mathrm{TD}=$ vocabulary ability consensus typically developing children.

\section{논의 및 결론}

본 연구에서는 학령기 단순언어장애아동 집단이 일반아동 집단 과 비교해 동음이의어 정의하기 능력에서 어떠한 차이가 있는지를 살펴보고자 하였다. 본 연구에서 사용한 동음이의어 정의하기는 한 개의 제시된 단어를 듣고 그 단어가 의미하는 두 가지 다른 뜻을 설명하는 과제로 보통명사, 추상명사, 동사, 형용사 단어들의 의미 자질에 대한 관찰, 분석, 표현 능력을 반영하는 정의정확도와 정의 유형을 분석하기 위해 사용되었다. 연구 결과, 첫째, 동음이의어 단 어 정의하기 과제에서 단순언어장애 집단은 어휘력검사 결과를 일 치시킨 일반아동 집단보다 전체 정의정확도 점수가 낮았다. 즉, 두 단어의 정의를 모두 정확하게 말했는지에 중점을 두어 동음이의어 의 전체 정의정확도를 분석했을 때는 단순언어장애아동 집단이 일 반아동 집단에 비해 비교적 수행이 떨어지기는 했지만, 이러한 집 단 간 차이가 통계적으로는 유의미하지는 않았다. 둘째, 우세의미 와 열세의미 각각에 대한 개별 정의정확도를 분석한 결과, 두 집단 모두 우세의미에 대한 정의정확도가 더 높았다. 단순언어장애아동 집단은 일반아동 집단보다 수행이 저조하였지만, 집단 간 차이는 우세의미와 열세의미 모두에서 통계적으로 유의미하지 않았다. 셋 째, 집단 간 정의유형을 분석한 결과, 정의정확도와 마찬가지로 우 세의미에서 두 집단 모두 정의유형 산출이 더 많았으며, 우세의미 와 열세의미에 따른 집단 간 정의유형 산출에서의 차이는 없었다. 정의유형 산출은 두 집단 모두 물리>기능> 관계>분류 순으로 나 타났다.

본 연구에서 학령기 단순언어장애아동 집단은 어휘력검사 결과 를 일치시킨 일반아동과 비교해 열세의미 정의정확도 점수에서 비 교적 낮은 수행을 보였지만, 이러한 차이는 통계적으로는 유의미하 지 않았으며, 우세의미 정의정확도에서도 일반아동 집단과 유사한 결과를 보여주었다. 또한 이러한 경향성은 정의유형 분석에서도 유 
사하게 나타났다. Lee와 Lee (2006)의 연구에서 학령 전 단순언어 장애아동 집단은 일반아동 집단과 비교해 열세정의에서 어려움을 보였다. 학령 전 아동의 경우에는 아직 경험하지 못한 단어가 많아 열세의미 정의에서 보다 많은 결함을 보였을 수도 있다. 하지만 본 연구에서 학령기 단순언어장애아동이 학령 전과 비교해 문해력과 학습 경험, 사회적 상호작용의 증가에 따라 학령 전과는 달리 열세 의미 정의 수행이 일반아동과 유사해졌다는 것은 이들의 학령기 언어적 경험이 맥락 활용과 상위인지 능력을 필요로 하는 동음이 의어 정의정확도와 정의 유형 산출에 영향을 미쳤음을 시사한다. 즉, 우세의미와 열세의미 처리 모두에서 일반아동 집단과 유사한 결과를 보여주었다는 것은 이들이 의미론적 처리에서 보이는 어려 움들이 처리 능력에서 기인한다기 보다는 Bishop (1994)에서 제안 한 발달적 수행 상의 결함으로 해석하는 것이 바람직함을 시사한 다. 본 연구에서 실시한 방법만으로 대상 아동들의 의미표상의 정 도를 명확하게 평가하기에는 어려움이 있겠지만, 이들의 낱말정의 능력이 일반아동과 비교해 현저하게 낮은 정도의 수행은 아니었으 며, 특히 이들이 단어 정의에 사용한 정의 유형들이 보다 나이 어린 일반아동들의 정의 유형 범주와 매우 유사하였다는 특성을 볼 수 있었다.

동음이의어 정의하기에서는 한 가지 단어의 두 가지 의미에 대해 각각 정의하기를 할 수 있어야 하므로, 아동이 두 가지 이상의 의미 를 이해하였는지를 동시에 평가하게 되며, 한 단어가 여러 다른 의 미를 가질 수 있음을 아는지와 더불어 단어지식에 대한 양적 및 질 적 수준을 평가할 수 있다. 예를 들어, ‘병’이라는 단어는 '몸이 아픈 질병'이라는 정의와 더불어, '마실 것을 담는 용기'라는 또 다른 뜻 도 있다. 따라서 동음다의어 습득에는 상위인지 능력과 탈맥락화 된 지식이 활용되어야 하므로 특히, 학령기에 접하게 되는 문해력 과 학습 경험의 영향이 이러한 단어정의에 영향을 미칠 수 있을 것 이다. 본 연구에서는 학령기 단순언어장애아동 집단을 일반아동 집단과 비교하는 과정에서, 단순언어장애아동 집단의 분포가 비교 적 고학년에 집중되어 생활연령이 좀 더 높았던 점으로 미루어 학교 에서의 학습 경험이 동음이의어 정의하기에 반영된 것으로 보인다.

본 연구에서 두 집단 간 차이가 없었던 점은 단순언어장애아동 일지라도 학령기 학습 경험을 통한 단어정의하기 능력이 일반 저학 년 아동의 수준까지는 발달하고 있음을 시사하는 결과로 보여진 다. 이러한 특징은 정의유형 반응에도 파악할 수 있었는데, 우세의 미 정의유형에 대한 반응유형은 두 집단이 유사하였다. 이러한 결 과로 보아 학령기 단순언어장애아동 집단은 어휘력 수준이 유사한 일반아동 집단과 비교해 단어의 의미자질에 대한 표상 능력에서 질적으로 크게 뒤지지 않음을 의미한다. 하지만, 단순언어장애아
동은 열세의미 정의하기에서 지각적 특징이 포함된 물리적 유형에 대한 반응이 가장 많았던 반면, 일반아동 집단은 기능적 그리고 관 계적 정의유형의 빈도가 높았다. 낱말을 정의하는 형태에서 단순언 어장애아동은 일반아동보다 상위 범주어를 포함하는 정의 사용에 어려움을 보이기도 한다(Gutierrez-Cleflen \& DeCurtis, 1999). 하지 만, 본 연구의 결과를 이와 같이 좀 더 발전시켜 해석하기 위해서는 단순언어장애아동과 어휘력뿐 아니라 생활연령을 일치시킨 일반 아동 집단과의 단어정의하기 수행을 비교해 볼 필요가 있을 것이다.

Cowles (2011)에 따르면, 모호한 단어의 처리 과정에는 단어를 접한 빈도와 습득 연령, 이웃 밀도 등이 포함된다. 따라서 이러한 요 인들은 동음이의어의 우세의미와 열세의미 처리에도 영향을 미치 게 되며, 우세의미가 되는 결정 요인에 특히 사용 빈도는 중요하게 작용한다고 할 수 있다. 본 연구에서는 검사용 동음이의어 단어 선 정 과정에서 빈도 조사 자료를 이용해 사용 빈도가 유사한 단어들 로 동음이의어의 우세의미와 열세의미 각각의 난이도에 대해 통제 를 하였지만, 아동 개인의 경험과 학습 능력, 사회경제적 환경(Kim, 2014), 그리고 단어에 대한 다양한 형태의 친숙도 등이 영향을 미칠 수 있었을 것으로 보인다.

동음이의어 정의하기는 단순언어장애아동들의 비전형적인 표현 의 질적 분석에 많은 도움을 줄 것으로 생각된다. 특히, 본 연구에서 는 외국에서 사용되는 검사도구인 'The Word Test' (Bowers et al., 2004)의 채점체계를 참고하여 전체 정의정확도를 산출하였으며 동 시에 우세의미와 열세의미 각각의 정의정확도를 함께 분석하여 비 교하였다. 비록 집단 간 차이가 유의미하지는 않았지만, 일반아동 집단에 비해 단순언어장애아동들이 열세의미 수행에 어려움을 보 였으므로, 이들의 언어중재 과정에서 열세의미 습득에 대한 고려 가 포함되어야 할 것이다. 국내에서도 표준화과정에 있는 '동음이 의어 단어정의하기' 과제의 경우, 채점 과정을 제시할 때 본 연구의 결과를 참조하여 보다 심층적으로 고려하는 것이 필요할 것이다. 즉, 학령기 단순언어장애아동은 표준화된 공식검사 도구를 사용 하여 평가하더라도 산출된 표현어휘에 대한 질적 평가가 보완되어 야 하며, 평가 결과는 이들의 단어 의미 지도 과정에서 고려되는 것 이 필요하다.

동음이의어의 의미 표상을 평가하기 위해서는 단어 수준의 이해 와 더불어 그 단어가 문장 속에서 어떤 의미로 사용되었는지를 아 는 지도 함께 평가할 수 있어야 한다. 따라서 단어정의하기를 통해 동음이의어를 평가하는 경우에도 아동이 실제로 해당 단어를 모두 이해하고 표현하는 지에 대해서는 평가가 어렵다. 따라서 Jang 등 (2014)이 지적하는 바와 같이 아동이 동음이의어가 갖는 어휘적 중 의성과 문장 내에서의 구문적 중의성에 대해 모두 이해하고 있는지 
를 보다 심층적으로 평가하고 비교할 필요가 있을 것이다. 이러한 점을 고려할 때, 동음이의어 정의하기 과제는 일반아동뿐 아니라 언어장애아동의 의미론적 결함을 평가할 수 있는 중요한 역동적 측 정치로 기능할 수 있을 것이다. 특히, 학령기 단순언어장애아동의 의미론적 결함이 읽기 이해에도 영향을 미치게 되므로, 동음이의 어가 포함된 문장읽기 과제에서 이들의 의미이해와 통사처리를 함 께 비교해보는 것도 매우 흥미로운 연구과제가 될 수 있을 것이다.

단순언어장애아동의 의미론적 결함이나 의사소통 관련 연구들 에서 이들에 대한 진단 준거는 매우 민감한 요인이다. 하지만, 몇몇 선행연구들에서는 전반적인 언어력 검사가 아닌 신뢰도와 타당도 가 입증되어 있는 표준화된 어휘력검사의 결과를 이들을 위한 진 단의 준거로 정하기도 한다(Botting, Riches, Gaynor, \& Morgan, 2010; Yang, Yim, \& Bae, 2015). 본 연구에서는 어휘력검사 결과와 더불어 비언어성 지능, 그리고 그밖에 언어치료사의 평가를 포함한 부모와 교사의 의견을 고려하여 선정하였다. 특히, 본 연구의 단순 언어장애아동들은 수용·표현어휘력 검사(REVT; Kim et al., 2009) 의 수용어휘력과 표현어휘력이 모두 $-1.25 \mathrm{SD}$ 이하인 아동들이었 다. 그럼에도 실험군 대상자가 언어능력의 일부인 어휘력만으로 선 정된 아동들이라는 제한점이 있으며, 이러한 어휘력 점수가 이들의 전반적인 언어능력을 모두 반영하지는 못한다는 점을 고려할 때, 결과 해석에서 참고되어야 할 것으로 생각된다.

본 연구에서는 기존 연구들과는 달리 학령기 단순언어장애아동 의 단어정의하기 연구임을 고려해 보통명사, 추상명사, 동사와 형용 사를 모두 검사 문항에 포함하였으나 문항 수의 제한으로 각 품사 별 정의정확도나 정의유형과 관련한 심층 분석을 실시하지 못하였 다는 점은 제한적으로 해석되어야 할 것이다. 또한 충분한 수의 아 동이 참여되지 않아 일반화하기까지는 더 많은 연구 결과가 축적되 어야 할 것이다.

\section{REFERENCES}

Bishop, D. V. (1994). Grammatical errors in specific language impairment: competence or performance limitations? Applied Psycholinguistics, 15, 507550 .

Booth, J. R., Harasaki, Y., \& Burman, D. D. (2006). Development of lexical and sentence level context effects for dominant and subordinate word meanings of homonyms. Journal of Psycholinguistic Research, 35, 531-554.

Botting, N., Riches, N., Gaynor, M., \& Morgan, G. (2010). Gesture production and comprehension in children with specific language impairment. British Journal of Developmental Psychology, 28, 51-69.
Bowers, L., Huisingh, R., LoGiudice, C., \& Orman, J. (2004). The Word Test 2 Elementary by LinguiSystems. Austin, TX: Pro-Ed.

Cairns, H. S., Waltzman, D., \& Schlisselberg, G. (2004). Detecting the ambiguity of sentences relationship to early reading skill. Communication Disorders Quarterly, 25, 68-78.

Corthals, P. (2010). Nine-to twelve-year olds' metalinguistic awareness of homonymy. International Journal of Language \& Communication Disorders, 45, 121-128.

Cowles, H. W. (2011). Psycholinguistics 101. New York, NY: Springer Publishing Company.

Doherty, M. J. (2004). Children's difficulty in learning homonyms. Journal of Child Language, 31, 203-214.

Gray, S. (2006). The relationship between phonological memory, receptive vocabulary, and fast mapping in young children with specific language impairment. Journal of Speech, Language, and Hearing Research, 49, 955969.

Gutierrez-Cleflen, V. F., \& DeCurtis, L. (1999). Word definition skills in Spanish-speaking children with language impairment. Communication Disorders Quarterly, 21, 23-31.

Jang, J., Jeong, M., \& Hwang, M. (2014). Comprehending and defining homonyms in school-aged children from multicultural families. Communication Sciences \& Disorders, 19, 71-79.

Kang, H. J., Hwang, M., \& Lim, J. A. (2013). The comprehension homonym in children with poor comprehension skills. Korea Journal of Learning Disabilities, 10, 161-176.

Kim, M. (2014). Characteristics of word definition in school-aged children from low-income families. Journal of the Korean Data Analysis Society, 16, 3277-3287.

Kim, Y. T., Hong, K. H., Kim, K. H., Jang, H. S., \& Lee, J. Y. (2009). Receptive \& expressive vocabulary test (REVT). Seoul: Seoul Community Rehabilitation Center.

Lee, E. Y., \& Ha, J. W. (2015). Semantic representation in children with specific language impairment. Communication Sciences \& Disorders, 20, 277289.

Lee, S. B., \& Lee, H. R. (2006). Lexical ambiguity comprehension of Korean children with specific language impairment. Korean Journal of Communication Disorders, 11, 14-29.

Lee, Y. (2005). A semantic organization of the words of children with specific language impairment. Korean Journal of Communication Disorders, 10, 43-57. 
Lee, Y., \& Kim, Y. T. (2003). Effects of semantic priming on word-finding ability of children with specific language impairment. Korean Journal of Communication Disorders, 8, 22-39.

Leonard, L. B. (2014). Children with specific language impairment (2nd ed.). Cambridge, MA: MIT Press.

Marinellie, S. A., \& Chan, Y. L. (2006). The effect of word frequency on noun and verb definitions: a developmental study. Journal of Speech, Language, and Hearing Research, 49, 1001-1021.

Marinellie, S. A., \& Johnson, C. J. (2002). Definitional skill in school-age children with specific language impairment. Journal of Communication Disorders, 35, 241-259.

Mazzocco, M. M. (1997). Children's interpretation of homonyms: a developmental study. Journal of Child Language, 24, 441-467.

McGregor, K. K., \& Appel, A. (2002). On the relation between mental representation and naming in a child with specific language impairment. Clinical Linguistics \& Phonetics, 16, 1-20.

Nelson, J. R., \& Stage, S. A. (2007). Fostering the development of vocabulary knowledge and reading comprehension though contextually-based multiple meaning vocabulary instruction. Education and Treatment of Children, $30,1-22$.

Park, H. W. (2014). Korean Comprehensive Test of Nonverbal Intelligence-sec- ond edition (K-CTONI-2). Seoul: Mindpress.

Park, K. A. \& Kim, Y. T. (2000). Comparison of verbal definitions of concrete nouns between normal children and language-delayed children. Korean Journal of Communication Disorders, 5, 20-37.

Rice, M. L., Buhr, J. C., \& Nemeth, M. (1990). Fast mapping word-learning abilities of language-delayed preschoolers. Journal of Speech and Hearing Disorders, 55, 33-42.

Rice, M. L., Buhr, J., \& Oetting, J. B. (1992). Specific-language-impaired children's quick incidental learning of words: the effect of a pause. Journal of Speech, Language, and Hearing Research, 35, 1040-1048.

Shin, M. J., \& Lee, H. R. (2015). Development and validation of the Urimal word semantic expressive test items. Journal of Speech-Language and Hearing Disorders, 25, 333-348.

Storkel, H. L., \& Maekawa, J. (2005). A comparison of homonym and novel word learning: the role of phonotactic probability and word frequency. Journal of Child Language, 32, 827-853.

Whitney, P. (1999). Psychology of language (S. B. Lee \& K. S. Han, Trans.). Seoul: Sigmapress.

Yang, Y., Yim, D., \& Bae, K. (2015). Predictors of word learning in children with specific language impairment. Communication Sciences \& Disorders, $20,1-12$. 
Appendix 1. Examples of flexible word and explanation of a definition

\begin{tabular}{lll}
\hline 1 & 눈 & -우리 몸에 있는 눈, 내리는 눈 \\
2 & 밤 & -깜깜한 밤, 먹는 밤 \\
3 & 병 & -담는 병, 아픈 병 \\
4 & 벌 & -혼나는 것, 날아다니는 벌 \\
5 & 말 & -타는 말, 말하는 말 \\
6 & 차 & -마시는 차(tea), 사람이 타는 차(car), 계산에서 빼기(-)의 의미 \\
7 & 상 & -한자 윗 상(上), 잘했을 때 주는 상, 밥 먹는 상 \\
8 & 풀 & -붙일 때 쓰는 학용품 풀, 잔디에 있는 풀(식물) \\
9 & 바람 & -자연에서 부는 바람, 하고 싶어하는 마음(희망) \\
10 & 쓰다 & -맛이 쓰다, 글씨 쓰다, 모자 쓰다, 사용하다 \\
11 & 적다 & -글씨 적다, 양이 적다 \\
12 & 달다 & -맛이 달다, 벽에 물건을 달다, 저울에 물건을 달아보다 \\
13 & 타다 & -차에(car)에 타다, 음식이 타다, 불에 타다, 차(tea)를 타다, 목이 말라 목이 타다 \\
14 & 고장 & -물건이 망가지다, 마을의 고장 \\
15 & 소화 & -음식을 소화하다, 불이 났을 때 소화하다, 내용을 이해하여 내 것으로 만들다 \\
\hline
\end{tabular}

Appendix 2. Examples of definition types and characteristics (Marinellie \& Chan, 2006; Park \& Kim, 2000 참조)

\begin{tabular}{|c|c|c|}
\hline 정의 유형 & 하위 정의유형 & 특징 \\
\hline 기능적 정의 & $\begin{array}{l}\text { 행위자 기능 } \\
\text { 도구적 기능 }\end{array}$ & $\begin{array}{l}\text { 목표 낱말의 움직임, 생물뿐만이 아니라 무생물이 행위자의 역할을 하는 경우에도 해당 } \\
\text { 목표낱말로 할 수 있는 기능 }\end{array}$ \\
\hline 관계적 정의 & $\begin{array}{l}\text { 배경 } \\
\text { 위치 } \\
\text { 비유/비교 } \\
\text { 관련실체 }\end{array}$ & $\begin{array}{l}\text { 목표낱말의 존재나 기능에 선행되는 시간, 조건, 이유(도구적인 기능이나 속성이 배경처럼 쓰인 } \\
\text { 경우는 배경에는 넣지 않고 도구적 기능이나 속성에만 포함시킴) } \\
\text { 목표낱말과 관련된 위치 } \\
\text { '-처럼', '같이' 등을 사용하여 다른 낱말로 비유하거나, '-보다'를 사용하여 비교 } \\
\text { 목표낱말과 특히 관련된 사물이나 사람 }\end{array}$ \\
\hline 물리적 정의(지각적 속성) & $\begin{array}{l}\text { 부분 } \\
\text { 속성(소리, 모양, 크기, 길이, 양, 색, 속도, } \\
\text { 맛, 세기, 무게 등) }\end{array}$ & $\begin{array}{l}\text { 목표낱말의 실물 중 특징적인 부분 } \\
\text { 동사일 경우, 부분적 설명 } \\
\text { 목표낱말 특유의 여러 가지 속성들 }\end{array}$ \\
\hline 분류적 정의 & $\begin{array}{l}\text { 하위수준 } \\
\text { 상위수준 } \\
\text { 동의(유사)어 }\end{array}$ & $\begin{array}{l}\text { 목표낱말의 종류 } \\
\text { 목표낱말이 속하는 범주 } \\
\text { 목표낱말과 비슷한 표현들 }\end{array}$ \\
\hline
\end{tabular}




\section{국문초록}

\section{학령기 단순언어장애 아동의 동음이의어 정의하기}

신문자 $\cdot$ 이희란 ${ }^{2}$

'조선대학교 언어치료학과, ${ }^{2}$ 부산가톨릭대학교 언어청각치료학과

배경 및 목적: 본 연구에서는 정의하기 과제를 통해 학령기 단순언어장애아동의 동음이의어 표현 특성을 살피고자 하였다. 동음이의 어 표현 과제는 단순언어장애아동의 의미론적 결함을 살펴볼 수 있는 적절한 도구이며, 이들이 학교생활에서 학업을 수행하고 교실담 화에 참여하는 데 도움을 줄 수 있다. 방법: 학령기 단순언어장애 15 명과 어휘력검사 결과를 일치시킨 일반아동 집단 15 명을 대상으로 15 개의 동음이의어 단어들의 전체 정의정확도, 우세의미와 열세의미 각각에 대한 정의정확도, 그리고 정의유형에 대해 두 집단의 수행 을 비교하였다. 결과: 첫째, 단순언어장애아동은 일반아동과 비교해 동음이의어 전체 정의정확도에서는 수행이 낮았지만 이러한 차이 가 통계적으로 유의미하지는 않았다. 우세의미와 열세의미를 개별적으로 비교한 정의정확도에서도 두 집단 간에 유의미한 차이는 없었 으며 두 집단 모두 우세의미에서 보다 더 높은 수행을 보여주었다. 셋째, 집단 간 정의유형을 분석한 결과, 정의정확도와 마찬가지로 우 세의미에서 두 집단 모두 정의유형 산출이 더 많았으며, 우세의미와 열세의미에 따른 집단 간 정의유형의 차이는 없었다. 우세의미와 열 세의미 정의유형을 합하여 집단 간차이를 비교한 결과, 집단 간차이는 없었으며, 정의유형 산출은 두 집단 모두 물리>기능>관계>분 류 순으로 나타났다. 논의 및 결론: 본 연구는 학령기 단순언어장애아동의 의미론적 능력 평가에서 동음이의어 정의하기의 질적 분석 의 중요성을 시사하며, 특히 단어 선정, 그리고 품사별 분석에 대한 후속 연구의 필요성이 제기되었다.

핵심어: 단순언어장애, 동음이의어, 단어정의, 언어 습득, 학령기 아동

\section{참고문헌}

강희정, 황민아, 임종아(2013). 읽기이해부진아동의 동음이의어 이해: 우세/열세의미와 반응시간을 중심으로. 학습장애연구, 10, 161-176. 김미배(2014). 초등 저학년 저소득층 아동의 명사, 동사 정의하기 능력. 한국자료분석학회지, 16,3277-3287.

김영태, 홍경훈, 김경희, 장혜성, 이주연(2009). 수용·표현어휘력검사(REVT). 서울: 서울장애인종합복지관.

박경애, 김영태(2000). 언어발달지체아동과 정상아동의 보통명사 정의하기 능력 비교. 언어청각장애연구, 5, 20-37.

박혜원(2014). 한국 비언어 지능검사(제2판). 서울: 마인드프레스.

신문자, 이희란(2015). 우리말 낱말표현검사 문항개발 및 타당도 연구. 언어치료연구, 25, 333-348.

양윤희, 임동선, 배경란(2015). 학령기 단순언어장애 아동의 어휘학습 예측요인: 의미점화 및 간섭 효과. 언어청각장애연구, 20, 1-12.

이승복, 이희란(2006). 단순언어장애 아동의 어휘적 모호성 이해. 언어청각장애연구, 11, 14-29.

이윤경(2005). 단순언어장애아동의 낱말 의미 구조화 특성. 언어청각장애연구, 10, 43-57.

이윤경, 김영태(2003). 의미적 점화가 단순언어장애 아동의 낱말찾기에 미치는 효과 언어청각장애연구, 8, 22-39.

이은영, 하지완(2015). 단순언어장애 아동과 일반 아동의 의미표상 비교. 언어청각장애연구, 20, 277-289.

장종윤, 정미란, 황민아(2014). 초등학교 저학년 다문화가정 아동의 동음이의어 이해와 정의하기. 언어청각장애연구, 19, 71-79.

Paul Whitney (1999). 언어심리학 (이승복, 한기선 역). 서울: 시그마프레스. 